\title{
Environmental Aspects of the European Experience in Landscape Planning
}

\section{Środowiskowe aspekty europejskiego doświadczenia $\mathrm{w}$ architekturze krajobrazu}

\author{
Bao Yu*1, Jianmei Wang*, Ya Li* \\ *Hebei Normal University of Science and Technology, \\ College of Horticulture Science and Technology, 066004, 360 West Section of Hebei Str., \\ Haigang District, Qinhuangdao, Hebei, People's Republic of China \\ **Zhejiang Industry Polytechnic College, College of Architectural Engineering, 312000, \\ 151 Qutun Road, Yuecheng District, Shaoxing City, Zhejiang, People's Republic of China \\ ${ }^{1}$ E-mail (Corresponding Author): bao-yu6457@ kpi.com.de
}

\begin{abstract}
Understanding all the possibilities of environmentally oriented landscape planning will contribute to the effective environmental planning of the territory and nature management in general. Accordingly, the purpose of the study was to investigate the experience of the European countries towards the introduction of an effective system of environmentally oriented landscape planning and improvement of territories, as well as their protection. For this purpose, it is necessary to comprehensively study the strengths and weaknesses of existing developments in the field of environmentally oriented landscape planning in Europe. An analysis of the best practices of environmentally oriented landscape planning in such countries as Great Britain, France, Germany, the Netherlands, etc. has been conducted. The findings allowed to state that the effectiveness of development and implementation of substantial planning for landscape design depends not only on the volume and depth of research, but to a very large extent from their reasonable and productive organisation. The paper summarises that in environmentally oriented landscape planning, it is first necessary to determine the reasons for planning. Before choosing the object and territory of planning, it is necessary to find out: who are the potential customers and investors - their goals and motivation; what are the problem situations and conflicts in nature management in the area; what is the practical use of the results of landscape planning; the purpose of the territory, including cartographic; the availability of source information, and more. And then make decisions regarding the stages of landscape planning, taking into account the environmental component and, accordingly, the implementation of the idea of landscape planning.
\end{abstract}

Key words: landscape, natural areas, landscape planning, ecology, environmental protection

\section{Streszczenie}

Zrozumienie wszystkich aspektów architektury krajobrazu zorientowanej na środowisko przyczyni się do efektywnego planowania środowiskowego terytorium i ogólnie do zarządzania przyrodą. W związku z tym celem badania było zbadanie doświadczeń krajów europejskich w zakresie wprowadzenia efektywnego systemu architektury krajobrazu zorientowanej na środowisko i poprawy obszarów, a także ich ochrony. W tym celu konieczne jest kompleksowe zbadanie mocnych i słabych stron istniejących rozwiązań w dziedzinie architektury krajobrazu zorientowanej na środowisko. Przeprowadzono analizę najlepszych praktyk architektury krajobrazu w takich krajach jak Wielka Brytania, Francja, Niemcy i Holandia. Wyniki pozwoliły stwierdzić, że skuteczność opracowania i wdrożenia planowania merytorycznego do projektowania krajobrazu zależy nie tylko od zakresu i głębokości badań, ale w bardzo dużym stopniu od ich racjonalnej organizacji. Stwierdzono, że w planowaniu krajobrazu zorientowanego na środowisko najpierw należy określić przyczyny planowania. Przed wyborem przedmiotu i terenu planowania należy dowiedzieć się: kim są potencjalni klienci i inwestorzy - ich cele i motywacja; jakie są sytuacje 
problemowe i konflikty w zarządzaniu przyrodą na danym terenie; jakie jest praktyczne wykorzystanie wyników planowania krajobrazu; cel terytorium, w tym opis kartograficzny; dostępność informacji źródłowych itp. Następnie należy podjąć decyzje dotyczące etapów planowania krajobrazowego z uwzględnieniem komponentu środowiskowego w celu odpowiedniej realizacji idei architektury krajobrazu.

Slowa kluczowe: krajobraz, obszary naturalne, architektura krajobrazu, ekologia, ochrona środowiska

\section{Introduction}

Landscape planning, including environmental, emerged in the field of landscape architecture in the last century, its principles and methods have become especially popular in conditions of aggravation of ecological situations and the need for their territorial and organisational solution (Kolbovskij, 2008; Lin et al., 2020). Today, environmentally oriented landscape planning is considered as a set of procedures and methods aimed at ensuring the territorial organisation of society in specific landscapes to achieve sustainable use of nature and preserve all the landscape functions. In accordance with the wording of the above, the object of this type of planning is a landscape, or a set of landscapes that are located in a certain area. In addition, territorial economic systems and infrastructure facilities located on it must be taken into account. A key feature of the importance of landscape planning is that it is performed based on special spatial planning, assessable methods that characterise the ability of landscapes to perform the outlined functions.

In this context, landscaping, including its environmental component, acts as an independent spatial planning process, which in certain conditions and, based on the objectives, can be integrated with spatial planning (Braga et al., 2020). In addition, certain criteria for successful landscaping, which are primarily focused on the protection and targeted use of landscapes, are included in territorial development projects and become mandatory in their implementation. An example is the experience of Germany, where spatial planning is carried out in conjunction with landscape planning. Landscape planning complements the territorial planning through landscape programmes at the public land level and general landscape plans at the regional and local levels. In different European countries, spatial planning is considered as environmentally friendly planning, a variety of which is landscape planning. In turn, it comes in the following forms: part of territorial planning; independent environmentally oriented land use planning; method of integration of environmental requirements in sectoral planning; combination of the listed forms.

The accumulated experience and specific models of landscape planning in European countries, despite the natural and socio-economic differences between them, show that this type of planning is aimed primarily at solving landscape and environmental problems and has a pronounced ecological orientation.
To date, there are still quite common opinions among experts in the field of territorial planning that the landscaping is concerned mostly with the landuse, using a landscape approach. This approach is to use landscape maps, structural and functional features of landscapes of different taxonomic rank, as well as the idea of landscapes as territorial complexes integrating natural and economic components. In this case, this refers not to a special landscape planning, but only the use of landscape approach when creating different plans for territorial development (Antipov, 2005). In each structural and information block of the territorial scheme, the functional roles of the landscape approach are ambiguous and differ significantly. Its main role is manifested in the study of the natural structure of territorial formation, spatial distribution of natural resources, development of tasks and measures for nature protection. In general, this is a natural block of the project, where the basic value should be given to the analysis of the landscape structure of the territory, which necessitates the use of a map. At the same time, landscape planning constitutes an independent type of territorial planning activity, where the basic object of planning are the landscapes, environmentally oriented planning, and ecological indicators of territories.

Landscape territorial organisation implies the accounting for the properties of a particular landscape in the development of nature and assessments of its resilience to a certain type of load, the degree of transformation, environmental resources, and ecological network, including protected areas. Its analysis is carried out on the basis of landscape information, which includes individual components and integral properties of landscapes through the consideration of various spatial models of the landscape morphological, positional and dynamic, positional and genetic, biocentric, basin and landscape dynamics, visual and aesthetic, etc. Although the study focuses on the experience of European countries, as an example of such landscape planning the North American method METLAND can be considered, which is used in urban planning as well as the Australian method SIRO-PLAN and LUPplan. Among the European methods, there are Dutch method APA, Slovakian LANDEP, methods of landscapeadaptive agriculture used in Russia, Ukraine, Moldova, Belarus, as well as methods of landscape planning used in the organisation and functional zoning of protected natural areas and certification of forestry enterprises (Rod'kin et al., 2008). 
A key feature of landscaping is that it is based on and carried out using a considerable amount of landscape information, which contains:

- $\quad$ analysis of the study of the spatial structure and condition of landscapes, their natural resource and aesthetic potentials;

- analysis of the resistance of landscapes to external anthropogenic influence, the effectiveness of their socio-economic, environmental and other functions;

- recommendations for changing, limiting, or expanding the above functions;

- recommendations for optimising the territorial structure of landscapes and preventing environmental hazards and threats to landscapes;

- recommendations for improving the use, transformation, reclamation, conservation, care and regulation of landscapes;

- search for optimal steps to resolve the conflicts of nature in different types of landscapes.

Thus, the understanding of all the possibilities of environmentally oriented landscape planning will contribute to the effective ecological planning of the territory and nature management in general. Accordingly, the purpose of the study was to investigate the experience of the European countries towards the introduction of an effective system of environmentally oriented landscape planning and improvement of territories, as well as their protection. For this purpose, it is necessary to analyse the strengths and weaknesses of the existing developments in the field of environmentally friendly landscape planning in $\mathrm{Eu}-$ rope.

\section{Literature Review}

An important stage of the study is to consider the ideas of the leading experts on the issue of landscape planning, taking into account the environmental component of this process. Landscapes are closely related to human well-being, but they are undergoing rapid and fundamental changes (Plieninger et al., 2015). Understanding the social transformations underlying these landscape changes, as well as the environmental and social consequences of landscape transformation, are key areas for landscape research. Within the framework of the study, six important areas of landscape research in Europe were reviewed and findings were synthesised. These findings can contribute to the study of ecosystem and societal changes, as well as key thematic priorities. These are six categories, namely: the relationship between people and the environment in landscapes; the structure of the landscape and the degree of land use; the history of the landscape; the driving forces, processes and actors of landscape transformation; significance of landscapes; and landscape management. Notably, these areas of knowledge can contribute to the study of changes in ecosystems and society, given the embedded multi-scale dynamics of socio-ecological systems; management of these systems and their ecosystem services; and the relationship between ecosystem services, human well-being, wealth and poverty. The synthesis method suggests that knowledge of past and present landscape models, processes, and dynamics provide guidelines for the development of support for sustainable management of socio-ecological systems in the future.

An integrated approach to landscape management is generally accepted, but its application is not at the desired practical level. Sectoral approaches to decision-making and planning processes still dominate. Izakovičová et al. (2019) deals with some aspects of integrated landscape management in Slovakia. The study reflects the current state of longstanding efforts and experience of the authors to integrate environmental knowledge into landscape management tools. The main methodological procedures required to achieve this goal is to analyse, compare, and confront the existing principles and tools used in the applied ecology of the landscape, as well as in legislation and planning practice. The landscape ecological base for the implementation of scientific advances in landscape management consists of two methods: landscape and ecological planning, and ecological network planning. These two methods have been introduced into nature protection legislation, territorial planning, watershed management, land use planning, forestry planning and flood prevention management. Such systematic landscape environmental norms in the practice of planning can be considered the basis of sustainable development.

Alizadeh \& Hitchmough (2019) indicates that urban landscapes play a significant role in supporting municipal, ecological and social systems. In addition, valuable environmental services and urban greenery provide social and psychological services that are very important for the livelihoods of modern cities and the well-being of urban residents. Admittedly, green spaces in the city, the method of urban landscape design and access to urban greenery can potentially affect the health, happiness, comfort, safety and security of urban residents. The urban landscape plays an important role in providing wildlife habitats, and an important type of vegetation for this is the plant-rich herbaceous vegetation that provides pollen and nectar, as well as the physical natural environment for the local fauna. Any factor that affects the urban landscape (such as climate change) will affect people's lives directly or indirectly. There is a universal consensus that temperatures have risen in most parts of the world over the past century, so the purpose of the Norton et al. study (2016) is the impact of climate change on the urban landscape. Effective biodiversity planning in large cities is becoming increasingly important as urban areas and their populations grow both to achieve conservation goals and because environmental communities support the services on which people depend. Landscape ecology provides an important framework for understanding and conserving urban biodiversity both 
within cities and in the regional context. It has played an important role in developing a significant and expandable body of knowledge about urban landscapes and communities. City-wide characteristics, including size, total greenery, age, and regional context, are important considerations for understanding and planning biotic assemblies across cities, but have received relatively little attention. The study of urban biodiversity is broader in scope and shows that longstanding principles on how the size of site, configuration, and composition affect biodiversity in urban areas. However, the subtle spatial scales in which urban areas are fragmented and the changed temporal dynamics compared to non-urban areas indicate the need to apply hierarchical multiscalar models of landscape ecology to the urban environment. Transferring the analysis of urban landscape biodiversity into planning activities remains a challenge due to the requirements for urban green spaces to provide a variety of functions. An increasing set of tools is available for this problem, requiring environmentalists to work with planners to address biodiversity issues. Conserving and improving biodiversity is only one area of urban planning, but it is becoming increasingly important in a rapidly urbanising world. Janssen \& Knippenberg (2012) emphasises that cultural landscapes are understood as a process aimed not only at protecting and preserving territories and natural resources. The new concepts and strategies for nature parks in the UK, France, and Germany propose to consider cultural landscapes in general and protected landscapes in particular, as well as a force to promote sustainable (regional) development. The concept of development and change is a key component of the very concept of sustainable development. This means preserving opportunities, as well as creating new resources for future generations. To implement sustainable territorial development, the emphasis in protected landscapes shifts from maintenance to development. As a result, landscape conservation strategies not only protect the cultural and natural heritage of cultural landscapes, but also enhance territorial dynamics that improve and reclassify territorial values such as (regional) identity and nature. Sustainability is increasingly positioned in the nature of changes, rather than in terms of any optimal state, model, or plan. Common historical roots, special landscape features, typical products, cultural traditions, as well as innovative projects are possible starting points for processes based on identity. In connection with the organisation of management, cultural landscapes can be recognised as arenas for sustainable development. As a result, cultural landscapes are not only goods and services that are of public interest and directly affect the social well-being of people, but also represent important assets for the development of cities and rural areas. Cultural landscapes are part of the capital of the region and the basis for the development of rural communities.
Considering the experience of landscape planning and environmental protection in European countries, Kartashov (2016) suggests that special attention should be paid primarily to areas that develop environmental democratic approaches. This is a combination of initiatives, mechanisms, funds, research programmes, and existing information to preserve the development of landscape and natural biodiversity; transparency of ecological information, and public participation in the decision-making process on issues related to environmental protection. Ustinova \& Aylikova (2019) suggests that environmentally oriented landscape planning is a strategic mechanism of European landscape planning, which ensures the implementation of the principles of sustainable development in territorial policy. The importance of environmentally oriented landscape policy is emphasised in the Guiding Principles of Sustainable Spatial Development of the European Continent, which notes that successful territorial development requires inclusion of landscape development issues in territorial planning and sectoral programmes and implementation of integrated policies aimed at simultaneous protection, management, and planning of landscapes. Due to environmentally oriented landscape planning it is possible to optimise the relationship between the population of European countries and natural components within specific areas. Such areas, in turn, are considered as components of a multilevel spatial system population - environment at local, regional, national, and transnational levels.

Kyvelou et al. (2019) aims to consider various ideas about the landscape and also demonstrates the ways in which the European Landscape Convention (ELC) of the Council of Europe (CE) contributes to the impact on national territorial planning systems. The study, which is interested in considering the effectiveness of landscape policy from a territorial standpoint, summarises the perception and understanding of the landscape as a link between nature and culture and reviews the literature to support the perspective of the European landscape model. Ultimately, it critically examines the Greek government's approach to landscape planning and management, revealing the catalytic role of the Council of Europe in revitalising the landscape dimension in Greece. The results indicate that this process has given a new impetus to territorial planning in Greece, providing a tool for management and coordination and evacuation policy, positively influencing the evolutionary paradigm of territorial planning. In addition, a decentralised approach has been adopted, identifying landscapes of particular value at the regional level in order to give them priority in terms of implementing coordinated governance mechanisms and management actions. The handbook titled Landscape planning and ecosystem services in Europe and beyond (Wende, 2019) is relevant for landscape planners and architects. But it is also useful for environmentalists and geographers, 
whether they are still studying or just starting their careers. This guide offers an extremely clear overview of the world of landscape planning and ecosystem services, gathering contributions from more than 45 international experts. It is noted that landscape planning and landscape policy play a significant role in Europe. Referring to the European Landscape Convention (2000), landscape planning should assess the natural and cultural resources and the cultural character of landscapes. It should identify and evaluate land use patterns, including the assessment of ecological and landscape aesthetic conflicts. Landscape planning should then define the quality objectives of the cultural landscape and establish conservation and development measures. Monitoring, public participation and communication on landscape issues are also important factors addressed by the European Landscape Convention. The results of landscape planning should be included in general strategic territorial planning tools, such as regional plans and/or local zoning plans. The main challenges for all countries that have signed and ratified the European Landscape Convention are to establish planning policies and tools as such, as well as to establish specific assessment methods. Here, the concept of ecosystem services can be useful in meeting the methodological requirements of the Convention on Landscape and Natural Resources Assessment. Brus et al. (2015) covers the restoration of landscapes that have been degraded in due to the extraction of minerals. Surfaces that are directly affected by mining and post-mining operations have become prominent in the field of restoration ecology. It is important to have a deeper understanding of sustainable landscape management in lowland European cultural landscapes. Sand and gravel sites have been selected as study sites where mining has been a major factor in land use in recent decades. Recovery after mining for each mining site was planned in accordance with the legally imposed technical and biological recovery protocols, as well as a specific document called the Biological Action Plan (BAP). The financial costs of BAP for individual research sites were compared with the monetary value of habitats over three time periods. The economic assessment was based on the method of assessing the environmental damage, conducted in Hesse (Germany). The findings suggest that the ecological restoration of areas after mining can lead to a higher monetary value of restored habitats compared to the original habitats that were destroyed by mining. Maksymenko (2012) the estimation of a modern stage of development of landscape planning in Ukraine is carried out. Problems of landscaping are addressed. The possibilities provided by the implementation of landscape planning procedures for ecological landscaping are outlined.

Elizbarashvili (2019) focuses on environmentally oriented landscape planning in the countries of south-eastern Europe. Javakheti National Park is a part of the plateau of volcanic origin, located between Georgia, Armenia, and Turkey. Javakheti is of particular cross-border importance due to its very high-altitude wetlands and high plateaus, which are the crossroads of bird migration routes between $\mathrm{Eu}-$ rope, Asia, and Africa. According to international environmental standards, the Javakheti wetlands could potentially be included in the Ramsar Convention Area since Georgia signed the Ramsar Convention in 1996. Currently, Javakheti ecosystems need to be protected, maintained, improved, and developed, preferably based on sustainable development and environmentally oriented landscape planning. There are several existing or proposed protected areas in the Javakheti protected area, including Borjomi-Kharagauli National Park, Mtirala National Park, Nedzvi and Tetrobi Reserves, the proposed Machahela National Park, Arpi Lake National Park (Armenia) and others. The creation of new protected areas in Javakheti and their connection to other existing protected areas through ecological corridors would not only serve the purposes of regional and cross-border cooperation, but would also serve as a prerequisite for creating an integrated network of protected areas of different categories in the region.

\section{Materials and Methods}

Existing literature data on the experience of environmentally oriented landscape planning in the European countries was used as study materials. The methodological basis of the study included general scientific and geographical methods of inquiry. The methods and principles of geosciences were applied, such as genetic, cartographic, comparative methods, the principles of causation. General scientific methods include historical, logical, structural-functional, statistical analysis. The methodology is also based on the system and process approaches. It is necessary to make a brief description of the basic methods of research. When using the cartographic method, the basis is a map or a set of maps that allow analysing existing landscapes, as well as making important corrective elements to the new landscape planning. Mapping is often combined with mathematical approaches. The comparative method of landscape and ecological research in combination with the method causal relationships allow singling out the main effective mechanisms among many existing approaches. The structural-functional and system analysis allow structuring data into complex algorithms of effective environmentally oriented landscape planning.

In addition, when studying the issues of environmentally oriented landscape planning and solving corresponding specific problems, the following methods can be used: ecological and economic balance of the territory, which is based on the analysis of the land use; assessment of the anthropogenic load, where for each category of land a certain score is awarded de- 
Table 1. List of European countries that have signed and ratified the European Landscape Convention

\begin{tabular}{|c|c|}
\hline Countries that have signed the European Landscape Convention & $\begin{array}{l}\text { Countries that have ratified or approved the Euro- } \\
\text { pean Landscape Convention }\end{array}$ \\
\hline $\begin{array}{l}\text { Belgium, Bulgaria, Croatia, Cyprus, Czech Republic, Denmark, } \\
\text { Finland, France, Greece, Ireland, Italy, Lithuania, Luxembourg, } \\
\text { Malta, Moldova, Norway, Poland, Portugal, Romania, San Marino, } \\
\text { Slovakia, Slovenia, Spain, Sweden, Switzerland, Armenia, Azer- } \\
\text { baijan, the Republic of Macedonia, Turkey, Ukraine }\end{array}$ & $\begin{array}{l}\text { Belgium, Norway, Denmark, Czech Republic, Cro- } \\
\text { atia, Ireland, Poland, Slovenia, Lithuania, Moldova, } \\
\text { Portugal, Romania, Bulgaria, San Marino, Armenia, } \\
\text { Republic of Macedonia, Turkey }\end{array}$ \\
\hline
\end{tabular}

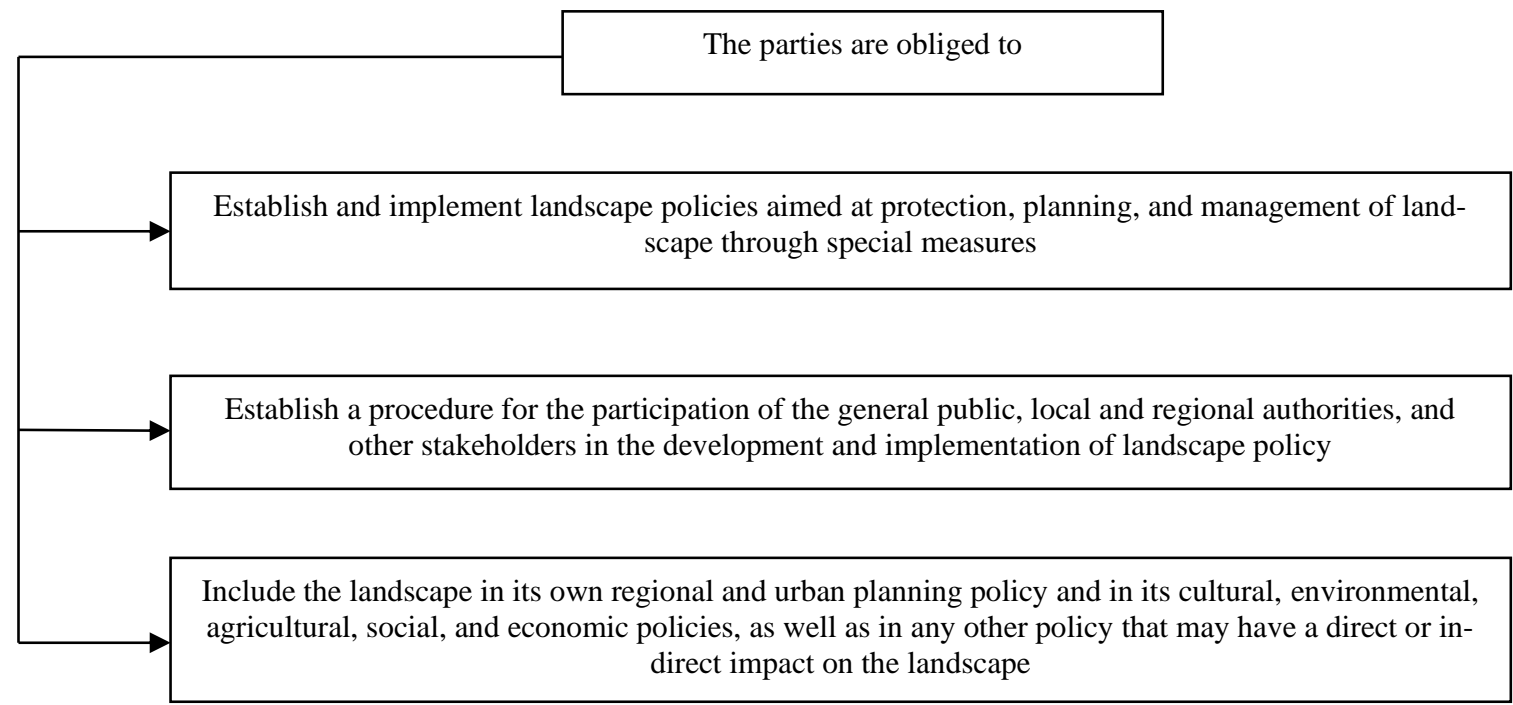

Figure 1. Obligations of each of the parties that have signed the European Landscape Convention

pending on the man-made impact; analysis of natural risks in which the frequency and intensity of the main types of natural risks are reflected; calculation of the ecological potential of the territory can be carried out by the territorial differentiation of the ratio of heat balance and humidity coefficient, etc.

The algorithm that is used in this study is aimed at analysing the existing experience of landscaping and environmentally oriented territorial planning in Europe. Therefore, in addition to the above methods, analysis and synthesis of information resources is necessary for the corresponding systematisation of the received information. European countries with high resource and natural potential and rich landscape diversity were selected for the study. Accordingly, the result of the study will be generalised recommendations for environmentally friendly landscape planning based on the best practices of the European countries. Dynamic changes in the landscape structure affect the number and distribution of organisms (Machar, 2020). Today, change in the land use is one of the main forces affecting ecosystem services in landscapes around the world. Human activity is transforming the earth faster and more than ever before in history. Human transformation of natural habitats and land use change is not only a lo$\mathrm{cal} /$ regional phenomenon, but can be seen as one of the important global change factors. Some of the effects of global change on biodiversity can only be studied on a landscape scale, such as climate change in plant areas. The landscape perspective contributes to a multi-scale approach to sustainable landscape management and landscape planning. In addition, the landscape scale is very useful for the innovative application of the general management paradigm for reusability in agriculture, forestry, and water management. Therefore, the need for sustainable landscape management and planning is urgent. Landscape conservation seems to be a new paradigm for biodiversity conservation.

\section{Results and Discussion}

First of all, it is necessary to note the contribution of the European Landscape Convention to the development of landscape planning in Europe. The member states of the Council of Europe have signed the European Landscape Convention (2020) to achieve sustainable development based on a balanced and harmonious relationship between social needs, economic activity, and the environment. 30 European countries have signed the European Landscape Convention, of which 17 have ratified or approved it. Table 1 lists the European countries that have signed and ratified the Convention.

The Convention states that the landscape plays an important social role in the cultural, environmental, and social spheres; is a resource for economic activity and its protection, planning; its management can help create new jobs.

Since the landscape is a fundamental component of the well-being of a person and the population of any country, the members of the Council of Europe, taking into account the rights and responsibilities of 
each individual, adopted a number of fundamental points in the Convention:

1) landscape is a territory (in the sense of how it is perceived), the nature of which is the result of the interaction of natural and (or) human factors;

2) landscape policy is the expression by the competent authorities of general principles, strategies, and guidelines to enable specific conservation, landscape planning, and management measures to be taken;

3) landscape planning is a proactive and forwardlooking activities to improve, restore, and create landscapes.

The main obligations of each of the parties that have signed this convention are indicated in the list which is shown in Figure 1. Environmentally oriented landscape planning in individual countries of the European continent has its own characteristics and specific features. Therefore, within the framework of the study, the experience of some countries will be considered to summarise their practices and trends in the development of landscape planning. Separate models and mechanisms of environmentally oriented landscape planning in different countries in most cases reflect the specific features of the political system, the problems of environmental protection of these states, as well as the specifics of territorial planning.

Landscaping in Germany emerged in the late $19^{\text {th }}$ century as a reaction to the industrialisation and destruction of nature. Thus, about $90 \%$ of Germany's forests are secondary, man-made forests. Admittedly, deciduous species were almost completely replaced by conifers. In the federal law of 1976, landscape planning was legally enshrined as a planning tool for landscape protection and care. This tool exists in practice not only at the federal but also at the regional level. Considering the main tasks of landscaping, they are focused on assessing and identifying the functions and properties of the landscape, as well as in developing proposals for sustainable conservation of air, water, lithosphere, climate, plants and animals, and most importantly aesthetic features of the landscape. Sustainable development of landscape planning in Germany has led to the fact that $26.9 \%$ of the country's area is protected natural areas. This has a positive effect on the overall environmental situation in the country (Mo et al., 2021). The German experience of landscape planning is a component approach to landscape analysis (soil, water, climate, lithological basis, fauna and flora). The most valuable methods in it are the detection and analysis of conflicts of nature management and assessment of the landscape according to the criteria of significance and sensitivity.

Environmentally oriented landscape planning in the Netherlands, unlike in Germany, has no deep traditions. This area is the most advanced in the protection of sea coasts, which is for the Netherlands one of the most important tasks not only in the field of ecology, but especially in the field of economic policy. Problems of air protection and climate change are solved through environmental protection programmes. The population and society in the Netherlands play a significant role in the development of landscape planning schemes. In the Netherlands, there are three levels of landscape planning: national, regional, and local. All three levels within their competence perform integrating functions and provide procedures for coordination of planning proposals. The national level is provided by the state. The $\mathrm{Na}$ tional Spatial Planning Programme is divided into four basic categories of development: the green course is the protection of the environment and nature management; yellow course - aimed at agricultural development; blue course - a combination of environmental and economic characteristics of the state, brown course - associated with integrative processes between agriculture and other sectors of the economy. Due to the fact that there is no law on nature protection in the Netherlands, there are no legal definitions of a national park in national environmental practice. The protected area in the Netherlands is $5.7 \%$ of the country's area. The advantage of the Netherlands over Germany is that more specific national and regional projects are being implemented there. At the local level, there is a significant legal division of specific planning mechanisms within individual settlements and beyond. One of the features of the Netherlands is a high degree of integration of environmental requirements into sectoral planning. France, along with other countries, has its individual specifics. It is traditionally a strong centre. There is a division of powers between the centre, the regions, and the communes, but there are almost no connections between them. There is no developed system of landscape planning there. Projects are implemented on a case-by-case basis. The national level (centre) provides the formulation of general principles of territorial development. The regional level implements the plans for the organisation of the territory and development programmes. At the commune level, the land use plans are being developed. The principle of voluntariness is dominant in environmentally oriented planning. The centre's decisions are stimulated by financial support. The tasks of environmentally oriented landscape planning in France are divided between different tools. Description, assessment of the state of the environment is carried out by various environmental and monitoring programmes. An environmental plan is being developed nationwide, which defines concepts for individual components of nature. The area of specially protected areas in France is $13.5 \%$ of its total area. It is worth noting that landscape areas in France are seen as a landscape and perceived as an aesthetic element. Therefore, the task of improving the landscape is understood as improving the landscape environment.

The main tasks of landscape planning in the UK are specific and are considered on a case-by-case basis. 
Protection of private property is the basic principle of this procedure. Considering areas that are subject to strict protection and other areas, the latter play a secondary role and the state may not control the degree of their protection. Notably, protected areas occupy $20.4 \%$ of the UK territory. Landscaping at the national level performs the tasks or functions of controlling the financing and handling of legal disputes. At the local level, the tasks are divided between the districts that develop strategic plans and the municipalities that make up the special land use plans. There is no such division in urban areas. Environmental planning is limited to the tasks of allocating protected areas. In Britain landscape acts as a visual and aesthetic category. Therefore, often landscape planning is reduced to mere appearance of the landscape and is not enshrined in law. Insufficient development of public management in nature law in British legislation and the strong position of private owners determine the conditions for the development of landscape planning in the UK. Landscape planning tasks are scattered across planning areas.

Within the framework of Spanish planning system, the concept of landscape planning does not exist as a single item. However, the tasks of landscape planning are largely performed by other mechanisms and methods. In general, there is a shift in views on the landscape not as an aesthetic category, but as a cultural and environmental value. Territorial planning in Spain is divided into sectors and levels. Regions have the right to spatial planning in cities. The main tools are regional and subregional plans for the organisation of the territory. However, there are difficulties between the centre and the regions in agreeing on the plans and interests of territorial planning. According to the national environmental law, the task of the state is to develop basic lines of nature protection. This task has not yet been completed. Some regions develop their own plans for territorial ecological development. At the local level, separate plans are being developed for communes within protected areas. Their area in Spain is $8.4 \%$. But at the local level, its tasks in the field of landscape planning are not defined. Resource use plans take precedence over territorial and sectoral development plans. The peculiarity of resource use plans in Spain is that they are made mainly for protected areas, and especially for the largest.

Slovakia has an interesting practice in developing environmentally oriented landscape planning projects - LANDEP (LANDscape-Ecological Planning) project, the main principles of which are: optimisation - offering the most convenient location for activity in the social sphere in terms of landscape and environmental patterns and the least danger - minimising the conflict between nature and the economy without slowing down economic development. The design sequence is as follows: Compilation of environmentally oriented landscape map $\rightarrow$ Functional interpretation of landscape properties (availability, humidity, nutrient requirement, insolation, dynamics of matter transfer, anthropogenic changes in vegetation, bearing capacity) $\rightarrow$ Estimation of importance of functional characteristics for selected species with regard to environmental impact $\rightarrow$ Assessment of the suitability of characteristics and constraints for the selected activity $\rightarrow$ Selection of appropriate areas and territories $\rightarrow$ Alternative proposals for the territory $\rightarrow$ Comparison of alternatives based on spatial conditions: size, neighbourhood, degree of similarity of proposals for neighbouring complexes, configuration of neighbouring complexes $\rightarrow$ Final proposal $\rightarrow$ Functional zoning $\rightarrow$ Detailed proposal with selection of sites for activities.

\section{Conclusions}

Summarising the experience in landscape planning, and especially environmentally oriented planning, it is possible to make certain generalisations that would further help to more clearly plan the relevant landscape processes. The complex of landscape planning by contributes to the improvement of the relationship between the requirements of environmental protection and socio-economic, cultural, and spiritual development and the interests of people. This in turn is an incentive to adhere to the postulates of sustainable development of countries and sustainable use of nature. Analysis of the experience of environmentally oriented landscape planning in countries such as the United Kingdom, France, Germany, the Netherlands, and Slovakia suggests that the effectiveness of development and implementation of environmentally oriented landscape planning depends to a large extent on its productive organisation. Talking about the tasks of planning, they will differ significantly depending on two main factors the purpose and specifics of planning and the characteristics of the considered area. First of all, it is necessary to analyse the reasons for planning. This means that before choosing a planning object and territory, it is necessary to find out: who are the potential customers and investors - their goals and motivation; what are the problem situations and conflicts in nature management in the area; what is the practical use of the results of landscape planning; the purpose of the territory, including cartographic; the availability of source information, and more. And then make decisions about the stages of landscape planning, taking into account the environmental component and, accordingly, the implementation of the idea of landscape planning.

Further line of the study presumes the analysis of the Asian and North American experience of environmentally oriented landscape planning to obtain the most complete picture of the process of landscaping, taking into account its environmental component. 


\section{References}

1. ANTIPOV A.N., 2005, Landscape planning: tools and application experience, Bonn, Irkutsk.

2. ALIZADEH B., HITCHMOUGH J., 2019, A review of urban landscape adaptation to the challenge of climate change, International Journal of Climate Change Strategies and Management, 11(2): 178-194, DOI: 10.1108/IJCCSM-10-2017-0179.

3. BRAGA A.C.R., SERRAO-NEUMANN S., de OLIVEIRA GALVAO C., 2020,. Groundwater management in coastal areas through landscape scale planning: A systematic literature review, Environmental Management, 65(3): 321-333.

4. BRUS J., DEUTSCHER J., BAJER A., KUPEC P., OLISAROVA L., 2020, Monetary Assessment of Restored Habitats as a Support Tool for Sustainable Landscape Management in Lowland Cultural Landscapes, Sustainability, 12(4): 1-15, DOI: $10.3390 / \mathrm{su} 12041341$.

5. ELIZBARASHVILI N., DVALASHVILI G., SULKHANISHVILI N., 2019, Selection principles and focuses of landscape planning of protected areas, International Journal of Geoheritage and Parks, 7(1): 33-44, DOI: 0.1016/j.ijgeop.2019.03.003.

6. European Landscape Convention, 2000, https://rm. coe.int/1680080621.

7. IZAKOVICOVA Z., MIKLOS L, MIKLOSOVA V., PETROVIC F., 2019, The Integrated Approach to Landscape Management - Experience from Slovakia, Sustainability, 11(17): 1-21, DOI: $10.3390 / \mathrm{su} 11174554$.

8. JANSSEN J., KNIPPENBERG L., 2012, From Landscape Preservation to Landscape Governance: European Experiences with Sustainable Development of Protected Landscapes, Studies on Environmental and Applied Geomorphology, 241-266.

9. KARTASHOV E., 2016, The European practice of implementing environmental strategies, Economy and State, 5: 17-19.

10. KOLBOVSKIJ E. J., 2008, Landscape planning, Nauka, Moscow.

11. KYVELOU S.S., GOURGIOTIS A., 2019, Landscape as connecting link of nature and culture: spatial planning policy implications in Greece, Urban Science, 3(81): 1-20, DOI: 10.3390/urbansci3030081.

12. LIN L., LI M., CHEN H., LAI X., ZHU H., WANG H., 2020, Integrating landscape planning and stream quality management in mountainous watersheds: A targeted ecological planning approach for the characteristic landscapes, Ecological Indicators, 117: 1-11.

13. MACHAR I., 2020, Sustainable Landscape Management and Planning, Sustainability, 12(6): 1-4, DOI: 010.3390/su12062354.

14. MAKSYMENKO N.V., 2012, Landscape planning as a means of ecological landscaping, Problems of Continuing Geographical Education and Cartography, 16: 65-68.

15. MO L., CHEN J., XIE Y., 2021, Assessment of landscape resource using the scenic beauty estimation method at compound ecological system, Environmental Science and Pollution Research, 28(5): $5892-$ 5899.

16. NORTON B.A., EVANS K.L., WARREN P.H., 2016, Urban Biodiversity and Landscape Ecology: Patterns, Processes and Planning, Current Landscape Ecology Reports, 1: 178-192, DOI: $10.1007 / \mathrm{s} 40823-016-0018-5$.

17. PLIENINGER T., KIZOS T., BIELING C., Le DUBLAYO L., BUDNIOK M.-A., BURGI M., CRUMLEY C.L., GIROD G., HOWARD P., KOLEN J., KUEMMERLE T., MILCINSKI G., PALANG H., TROMMLER K., VERBUNG P.H., 2015, Exploring ecosystem-change and society through a landscape lens: recent progress in European landscape research, Ecology and Society, 20(2): 1-10, DOI: $10.5751 / E S-07443-200205$.

18. ROD'KIN O.I., ROMANOVSKIJ Ch. A., POZNJAK S.S., 2008, Environmental management, Nauka, Minsk.

19. USTINOVA I.I., AYLIKOVA H.V., 2019, Landscape planning as ecological basis for territorial planning, Urban Planning and Spatial Planning, 70: 574587.

20. WENDE W., 2019, Landscape planning and ecosystem services in Europe and beyond, Ecosystems and People, 15(1): 347-350, DOI: $10.1080 / 26395916.2019 .1698278$. 